To cite this article: Mustapha Imam, Muntaka Muhammad, Mabruka Abubakar Abba \& Patrick Osaze ljiekhuamhen (2020) Assessment of Capacity Building Efforts of Library and Information Professionals in University Libraries in Nigeria. Information Impact: Journal of Information and Knowledge Management, 11:4, 25-36, DOI: https://dx.doi.org/10.4314/iijikm.v11i4.3

To link to this article: https://dx.doi.org/10.4314/iijikm.v11i4.3

\title{
Assessment of Capacity Building Efforts of Library and Information Professionals in University Libraries in Nigeria
}

\author{
${ }^{1}$ Mustapha Imam \\ ${ }^{1}$ Muntaka Muhammad \\ ${ }^{1}$ Mabruka Abubakar Abba \\ ${ }^{2}$ Patrick Osaze ljiekhuamhen \\ ${ }^{1}$ Sa"adatu Rimi College of Education Library, Kumbotso, Kano, Nigeria \\ ${ }^{2}$ Federal University of Petroleum Resources Library, Effurun, Nigeria
}

\begin{abstract}
This study assessed the capacity building efforts of library and information professionals in university libraries in Nigeria. The study adopted a descriptive survey design and a structured questionnaire was the instrument used for data collection. The exact population of the study is 238 librarians in the university libraries in South- South, Nigeria. The total enumeration sampling technique which involves studying the entire respondents was employed for the study. Two hundred and thirty eight copies of the questionnaire were distributed to the respondents; the researchers were able to retrieve only 211 questionnaires. Hence there was $89 \%$ response rate. The data collected for this study were analyzed using simple percentage and frequency counts using tables. The findings of the study revealed that the capacity building needs of library and information professionals in university libraries were majorly troubleshooting new technologies, academic research, internet search skills, e-library management, and library automation, among others. Additionally, findings show clearly that on the job training, in-house training, participation in professional association, lecture/ discussion and exercises, and job rotation were the major methods of building the capacity of library and information professionals. It was recommended that sufficient funding should be allocated to university libraries for the organization of capacity building programmes for library and information professionals, among others.
\end{abstract}

Keywords Assessment, Capacity Building, Library and Information Professionals, University Libraries

CONTACT Mustapha Imam, Muntaka Muhammad, Mabruka Abubakar Abba and Patrick Osaze ljiekhuamhen ijiekhvamhen.osaze@fupre.edu.ng Sa'adatu Rimi College of Education Library, Kumbotso, Kano,Nigeria and Federal University of Petroleum University Library, Effurun, Nigeria.

2020 The Authors Published with License by Information Impact 


\section{Introduction}

Capacity building is the process organizations maintain to develop their workforce to realize their full potential in view of meeting the organization's current and future goals. United Nations Building Programme (2009) defined capacity building as the process through which individuals, organizations and societies obtain, strengthen and maintain the capabilities to set and achieve their own building objectives over time. From the aforementioned definition it is glaring that capacity building help to set and achieve developmental objectives for organizations to succeed. In the same vein, university libraries across the globe are exploring viable means of developing their capacity to enhance their competitiveness and efficiency. Building capacity of employees enhances efficiency, competitiveness and customers satisfaction. Bhattacharjee and Bhattacharjee (2014) posited that in the broad sense, capacity building in libraries is concerned with basically library and information science professional development, library development, and institutional and legal framework development. It is glaring that capacity building in university libraries has three dimensions, the LIS professional development, the university library development and institutional and legal framework development (Bhattacharjee and Bhattacharjee, 2014). This paper will be focused on the capacity building of library and information professionals in university libraries in Nigeria. Capacity building of library and information professionals is currently a topical issue in the literature as no university library can strive without a competent workforce (Ajeemsha \& Madhusudhan, 2012). Ajeemsha and Madhusudhan (2012) further posited that staff development is a significant issue in a changing library environment as well-equipped professional librarians are key resources to developing and maintaining a high quality library. The medical profession, law, banking, engineering among others fields are swiftly embracing technological changes associated with this $21^{\text {st }}$ century that could help boost their service delivery. The library and information science profession should as a matter of urgency move along with the trend to be able to meet the current and future needs of their users. To achieve this aim the need to build the capacity of library and information professional becomes inevitable.

However, in this digital age, university libraries in Nigeria are increasingly embracing technologies for the enhancement and marketing of their services and resources. This technological advancement in university libraries has prompted the need for capacity building of library and information professionals to keep them abreast of how to explore and use the emerging cutting edge technologies for the advancement of their services and resources. The scenario is same in India as Ajeemsha and Madhusudhan (2012) posited that library professionals, especially academic librarians in India are facing challenges in the profession due to the rapid technological changes with the development of cutting-edge technologies in library work/services. Capacity building efforts in university libraries is faced with enormous challenges which are not limited to inadequate funding, lack of willingness by library management to build capacity of professionals, lack of interest to attend capacity building programmes by professionals in university libraries to mention but a few. This study takes a critical look at the capacity building scenario of library and information professionals in university libraries in Nigeria. Currently, only few studies have been undertaken on the capacity building of library and information professionals in university libraries in Nigeria. This lacuna in the literature prompted the need for the study.

\section{Objectives of the Study}

The specific objectives of the study are:

$\checkmark$ To find out the capacity building needs of Library and information professionals in university libraries in Nigeria. 
$\checkmark \quad$ To ascertain the method of capacity building for Library and information professionals in university libraries.

$\checkmark$ To examine the frequency of developing the capacity of Library and information professionals in university libraries.

$\checkmark$ To investigate the benefits of capacity building programmes on the professional development of Library and information professionals in university libraries.

$\checkmark$ To identify the barriers to capacity building for Library and information professionals in university libraries.

\section{Research Questions}

The following research questions were formulated to guide the study:

$\checkmark$ What is the capacity building needs of Library and information professionals in university libraries in Nigeria?

$\checkmark$ What is the method of capacity building for Library and information professionals in university libraries?

$\checkmark$ What is the frequency of developing the capacity of Library and information professionals in university libraries?

$\checkmark$ What is the benefits of capacity building programmes on the professional development of Library and information professionals in university libraries?

$\checkmark$ What is the barriers to capacity building for Library and information professionals in university libraries?

\section{Literature Review}

In a study by Bhattacharjee and Bhattacharjee (2014) on boosting capacity of library and information professionals via training in Barak Valley (Assam), It was revealed that $56(84.8 \%)$ of the respondents indicated library automation training, followed by $52(78.8 \%)$ ICT skill development training . Furthermore, $47(71.2 \%), 43(65.1 \%), 40(60.6 \%)$ professionals felt human resource management skills, management of e-resource/ Internet training, digital library training respectively. Moreover, 36 (56.4\%), 31 (46.9\%), 29 (43.9\%), 25 (37.8\%), 21 (31.8\%) and 20 (30.3\%) professional respectively opined user education training, research, development training, communication skills training, reference sources and services training, project management training, Statistics management skills are also essential areas of training program and place. Ogunmodede and Mafelu (2012) studied capacity building programmes for library staff in university of Ibadan and University of Lagos Libraries. The findings revealed that $124(95.4 \%)$ respondents felt that capacity is needed to improve staff efficiency, enhances staff productivity and help to cope with changes in library as a result of modern technologies. Also, 123 (94.6\%) agreed that it brings out the best in library staff while $120(92.3 \%)$ saw it as a motivation for library staff. Bhatti and Nadeem (2014) assessed training needs of LIS professionals: A prerequisite for developing training programs in university libraries of Pakistan. The results obtained show that LIS professionals need training related to troubleshooting new technologies, endnote, data compression, Internet, social media such as Facebook, Blog, Flickr, Twitter, and online databases.

University libraries explore various methods for building the capacity of their library and information professionals. Njeze and James (2013) studied capacity building initiatives in preservation techniques: a case study of Nigerian universities. The study revealed that libraries surveyed conduct more seminars $(33.93 \%)$ and in-house training $(30.36 \%)$ for its employees. Capacity building initiatives related to conferences (17.86\%) appear in the background. Finally, it appears that personal development (10.71\%) and e-learning $(7.14 \%)$ demonstrating initiatives are 
little used. More so, Agadi, Shokeen and Choukimath (2008) posited that efficient manpower training programmes must be organized from time to time for librarians via the following methods; Practical hands-on training to library personnel, Continuing Education Programmes [CEPs], Educational Tour (Library cooperation), Workshops, Conferences, Seminars and Co-curriculum activities. Khan and Rafiq (2013) studied effective In-service training for librarians in Pakistan. The findings of the study revealed that practical work, lecture/discussion and exercises were methods of providing in-service training for librarians in Pakistan. Similarly, Nwabueze and Anike (2016) studied mentoring strategies in use for professional development of librarians in South-East federal university libraries. The study revealed that sponsorship to conferences, seminars and workshops, and participation in professional associations and orientation programmes for newly employed librarians are among the programmes through which the librarians are mentored in federal universities southeast Nigeria.

However, Idiegbeyan-Ose, Ohaegbulam and Osayande (2015) studied conference/workshop attendance by librarians: Benefits, challenges, and prospects. The study revealed that $42(79.2 \%)$ of the respondents attend a conference or workshop once a year, $9(17.0 \%)$ attend twice a year, $2(3.8 \%)$ attend three times a year, and no respondents attend four times or more. Eke (2011) did an empirical study of the impact of NLA conference attendance on librarians' professional development. The study revealed that majority of the librarians (128) have attended NLA conference 2-5 times $(69.1 \%)$ and only few (8) have attended more than 10 times (4.3\%). Those with more experience in the profession have attended more than ten times, especially academic librarians. Newer librarians are most of those who have attended once (15.6\%). Adekanye and Ogunleye (2016) studied training for librarianship development in Nigeria: How do librarians want it? The findings on frequency of training revealed that $39(33.9 \%)$ of the respondents indicated twice a year, 19(16.5\%) indicated yearly, 5(4.3\%) indicated quarterly, 4(3.5\%) indicated every two years, others 19(16.5), while 29(25.2) indicated they have attended none of the training programmes.

Hosein and Bowen-Chang (2011) examined the effectiveness of cataloguing training of professionals at the St Augustine Campus Libraries of the University of the West Indies, during the period 2005-2010, with emphasis on the cataloguing of special formats and the overall importance of continuing education. The findings clearly demonstrated the effectiveness of cataloguing training in supporting the cataloguers in their thrust to improve and upgrade their professional skills, and thereby facilitate the transfer of knowledge and practices to entry-level cataloguers. Malik (2016) reported that after participating in a professional development program about adult learning theory, librarians gain a greater awareness of student development, enabling them to more successfully in tailoring their interactions. Ojowhoh (2016) studied staff development and library services in academic libraries in Bayelsa and Delta States. The result shows that training and development brings about job efficiency, motivation and satisfaction. The study concluded that training and development have positive influence on library services and as such, should be given priority. Oke and Oguntuase (2010) affirmed that training and development of library staff in any academic library contributes significantly to productivity because trained staff are motivated and better equipped to utilize their knowledge, skills, and abilities. Word Quotient (2009) outlined the benefits of training for an employee to include increased job satisfaction, increased motivation, and improved performance. Bamidele, Omeluzor, Imam and Amadi (2013) studied training of library assistants in academic library: A study of Babcock University library, Nigeria. The findings revealed that $18(60 \%)$ and 9 (30\%) of the respondents strongly agreed and agreed, respectively, that training enhances their job performance. The result further showed that training of library assistants will help them cope with the 21st-century library challenges, foster their interest to become librarians in the future, understand the policies guiding the library, and help in the overall services of the library to her users 
However, Owusu-Acheaw (2017) studied professional development programmes for Polytechnic Library Staff in Ghana: Challenges and Prospects. The study revealed that among the challenges listed, 25 of the respondents representing 34\% indicated lack of financial assistance from the institution for professional development as the main challenge. Bhattacharjee and Bhattacharjee (2014) studied capacity building through training program for LIS professionals: A survey on various libraries in Barak Valley (Assam). The findings revealed that 40(60.6\%) professionals indicated lack of training programs at a convenient time is the major problem they face which is followed by 37 (56.0\%) professionals, who feel the problem was due to lack of permission from higher authority. Moreover, 36 (54.6\%), 32 (48.8\%), 30 (45.5\%), 28 (42.3\%), 19 (28.7\%), 15 (22.7\%) and 10 (15.2\%) LIS professionals respectively felt less number of training programs organized in the locality, lack of funding from the employers, lack of time for attending training, communication backwardness, lack of willingness to attend training program, training is expensive for them and training is not compulsory for promotion respectively. Furthermore, 8 (12.1\%) professionals also felt that there were some other barriers to participate in the training program. Okiy (2004) carried out an In-house staff training programme at Delta State University Library, Abraka, Nigeria. The problems encountered in the course of the training include limited ICT skills of most of the staff being trained. This slowed down the pace of the training on the computers. In a study by Abba and Dawha (2009) on assessment of personnel training needs in the Ibrahim Babangida Library, Federal University of Technology, Yola, Nigeria. It was revealed from the study that all respondents strongly agreed that funding is a factor that militates against training, while half strongly agree that lack of qualifications is a factor. More than one third agrees that shortage of personnel is a militating factor. Therefore, funding can be considered as a key requirement to the successful and consistent training of library professionals in academic libraries.

\section{Methodology}

Descriptive survey research design was adopted for the study and the instrument adopted to elicit data from the respondents was a structured questionnaire with the aid of three research assistants that assisted in distributing and explaining aspects of the questionnaire not clear to the respondents. The population of the study comprises library and information professionals in university libraries in South- South, Nigeria. The exact population of the study is 238 librarians in the university libraries in South- South, Nigeria. The researchers employed the total enumeration sampling technique which involves studying the entire respondents. Two Hundred and Thirty Eight (238) copies of the questionnaire were distributed to the respondents; the researchers were able to retrieve only Two hundred and Eleven (211) copies of the questionnaire. Hence there was $89 \%$ response rate. The data collected for this study were analysed using simple percentage and frequency counts presented in tables.

\section{Findings and Discussion}

Analysis of Demographic Distribution of Respondents

Table 1: Gender Distribution of the Respondents

\begin{tabular}{|l|l|c|}
\hline Gender & Frequency & Percentage \\
\hline Male & 139 & $66 \%$ \\
\hline Female & 72 & $34 \%$ \\
\hline Total & 211 & $100 \%$ \\
\hline
\end{tabular}

From Table 1 above, 139(66\%) of the respondents were male, while 72(34\%) of the respondents were females. 
Table 2: Questionnaire Response Rate

\begin{tabular}{|l|l|l|}
\hline No of Questionnaires Distributed & No of Questionnaires Retrieved & Percentage \\
\hline 238 & 211 & $89 \%$ \\
\hline
\end{tabular}

From Table 2 on the questionnaire response rate above, out of the 238 copies of the questionnaires distributed to the respondents, the researchers were able to retrieve 211 copies. Hence there was $89 \%$ response rate.

Research question one: What are the capacity building needs of Library and information professionals in university libraries in Nigeria?

Table 3: Capacity building needs of Library and information professionals in university libraries

\begin{tabular}{|l|c|c|}
\hline Capacity building needs & Frequency & Percentage \\
\hline Cataloguing and Classification & 147 & $70 \%$ \\
\hline Library Automation & 189 & $90 \%$ \\
\hline E-library Management & 204 & $97 \%$ \\
\hline Troubleshooting New Technologies & 211 & $100 \%$ \\
\hline Human Resource Management skills & 128 & $61 \%$ \\
\hline Serial Management skills & $\mathbf{8 7}$ & $\mathbf{4 1 \%}$ \\
\hline Communication/ Interpersonal relationship skills & 165 & $78 \%$ \\
\hline Promotion of Services and Resources & 57 & $27 \%$ \\
\hline Academic Research & 211 & $100 \%$ \\
\hline Project Management skills & 37 & $18 \%$ \\
\hline Internet Search Skills & 211 & $100 \%$ \\
\hline
\end{tabular}

From Table 3on the capacity building needs oflibrary and information professionals, 211(100\%) of the respondents indicated Troubleshooting New Technologies, Academic Research, and Internet Search Skills, 204(97\%) of the respondents indicated E-Library Management, 189(90\%) of the respondents indicated library automation, 165(78\%) of the respondents indicated communication/ Interpersonal relationship skills, $147(70 \%)$ of the respondents indicated cataloguing and classification skills, $128(61 \%)$ of the respondents indicated human resources management skills, $87(41 \%)$ of the respondents indicated serial management skills, 57(27\%) of the respondents indicated promotion of services and resources and lastly 37(18\%) of the respondents indicated project management skills.Therefore, capacity building needs of LIS professionals are troubleshooting new technologies, academic research, internet search skills, e-library management, library automation, cataloguing and classification, communication/interpersonal relationship skills and human resource management skills

Research question two: What are the methods of capacity building for Library and information professionals?

Table 4: Method of capacity building for Library and information professionals

\begin{tabular}{|l|c|c|}
\hline Method of Capacity Building & Frequency & Percentage \\
\hline On the Job Training & 211 & $100 \%$ \\
\hline
\end{tabular}




\begin{tabular}{|c|c|c|}
\hline Job Rotation & 146 & $69 \%$ \\
\hline In-House Training & 207 & $98 \%$ \\
\hline Seminar & 67 & $32 \%$ \\
\hline Conferences & 78 & $37 \%$ \\
\hline Workshop & 39 & $18 \%$ \\
\hline Lecture/discussion and exercises & 157 & $74 \%$ \\
\hline Participation in professional associations & 201 & $95 \%$ \\
\hline Orientation programmes & 78 & $37 \%$ \\
\hline E-learning & 34 & $16 \%$ \\
\hline Library Tour & 27 & $13 \%$ \\
\hline Mentoring & 89 & $42 \%$ \\
\hline Academic Education & 44 & $21 \%$ \\
\hline
\end{tabular}

From Table 4 above on the method of capacity building for library and information professionals, 211(100) of the respondents indicated on the job training, 207(98\%) indicated in-house training, 201(95\%) indicated participation in professional associations, 157(74\%) indicated lecture/ discussion and exercises, 146(69\%) indicated job rotation, 89(42\%) indicated mentoring, 78(37\%) indicated conferences and orientation programmes, 67(32\%) indicated seminar, 44(21\%) indicated academic education, among others.Therefore, the methods of capacity building in university libraries are job training, in-house training, lecture/discussion and exercises, participation in professional association and job rotation

Research question three: How frequently do library and information professionals attend capacity building programmes?

Table 5: Frequency of developing the capacity of Library and information professionals in University Libraries

\begin{tabular}{|l|l|l|}
\hline Frequency of developing Capacity & Frequency & Percentage \\
\hline Quarterly & 12 & $6 \%$ \\
\hline Twice a Year & 23 & $11 \%$ \\
\hline Yearly & 51 & $24 \%$ \\
\hline Every Two Years & 125 & $59 \%$ \\
\hline None & - & - \\
\hline Total & 211 & $100 \%$ \\
\hline
\end{tabular}

From Table 5 above on the frequency of developing the capacity of library and information professionals, $125(59 \%)$ indicated they attend capacity building programmes every two years, $51(24 \%)$ indicated yearly, 23(11\%) indicated twice a year, $12(6 \%)$ indicated quarterly. 
Research question four: What are the benefits of capacity building programmes on the professional development of library and information professional?

Table 6: Benefits of capacity building programmes on the professional development of Library and information professionals

\begin{tabular}{|l|c|c|}
\hline Benefits of Capacity Building & Frequency & Percentage \\
\hline Upgrade of professional skills & 211 & $100 \%$ \\
\hline Effective Service Delivery & 211 & $100 \%$ \\
\hline Timely Service Delivery & 176 & $\mathbf{8 3 \%}$ \\
\hline $\begin{array}{l}\text { Error Free Cataloguing and Classification of library } \\
\text { materials }\end{array}$ & 102 & $\mathbf{4 8 \%}$ \\
\hline Better E-Library Management & $\mathbf{1 8 7}$ & $\mathbf{2 0 1}$ \\
\hline $\begin{array}{l}\text { Better Communication/ Interpersonal Relationship } \\
\text { with users }\end{array}$ & $\mathbf{1 1 4}$ & $\mathbf{5 4 \%}$ \\
\hline Enhance Promotion of library services and resources & $\mathbf{2 1 1}$ & $\mathbf{5 8 \%}$ \\
\hline $\begin{array}{l}\text { Increase knowledge on the use of ICT in university } \\
\text { libraries }\end{array}$ & 122 & $\mathbf{5 4 \%}$ \\
\hline $\begin{array}{l}\text { Better academic research written by Information } \\
\text { Professionals }\end{array}$ & & \\
\hline $\begin{array}{l}\text { Improved understanding about the Librarianship } \\
\text { Profession }\end{array}$ & & \\
\hline
\end{tabular}

From Table 6 above on the benefits of capacity building programmes, 211 (100\%) of the respondents indicated upgrade of professional skills, Effective service delivery, and Increased knowledge on the use of ICT in university libraries, 201(95\%) indicated better communication/ interpersonal relationship with users, 187(89\%) indicated better E-Library Management, 176(83\%) indicated timely service delivery, 122(58\%) indicated better academic research writing by information professionals, $114(54 \%)$ indicated enhance promotion of library services and resources, improved understanding about the librarianship profession, and 102(48\%) indicated error free cataloguing and classification of library materials. Therefore, the benefits of capacity building programmes on the development of LIS professionals include upgrade of professional skills, effective service delivery, increased knowledge on the use of ICTs in university libraries, better communication/interpersonal relationship with users better e-library management, timely service delivery, better academic research written by information professionals, enhanced promotion of library services and resources and improved understanding about the librarianship profession.

Research question five:What are the barriers of capacity building for Library and information professionals in university libraries?

Table 7: Barriers of capacity building for Library and information professionals in university libraries

\begin{tabular}{|l|c|c|}
\hline Barriers of Capacity Building Programmes & Frequency & Percentage \\
\hline Inadequate funds to organize capacity building programmes & $\mathbf{2 1 1}$ & $100 \%$ \\
\hline
\end{tabular}




\begin{tabular}{|l|c|c|}
\hline Inadequate time to attend capacity building programmes & 142 & $\mathbf{6 7 \%}$ \\
\hline No proper needs assessment before organizing capacity building programmes & 203 & $\mathbf{9 6 \%}$ \\
\hline $\begin{array}{l}\text { Lack of willingness to attend training program by library and information } \\
\text { professionals } \\
\text { Limited skills of most of the staff being trained has slowed down capacity } \\
\text { building programmes }\end{array}$ & $\mathbf{3 1}$ & $\mathbf{1 1 2}$ \\
\hline $\begin{array}{l}\text { Inadequate training facilities and equipment } \\
\text { No written capacity building policy }\end{array}$ & $\mathbf{1 9 4}$ \\
\hline $\begin{array}{l}\text { Most of the Capacity building programmes are poorly introduced and } \\
\text { uncoordinated }\end{array}$ & $\mathbf{2 1 1}$ & $\mathbf{1 0 0 \%}$ \\
\hline $\begin{array}{l}\text { No proper evaluation of capacity building programmes for future improvements } \\
\text { Inadequate support from university management }\end{array}$ & $\mathbf{9 6 2}$ \\
\hline
\end{tabular}

From Table 7 above on the barriers of capacity building programmes 211(100\%) of the respondents indicated inadequate funds to organize capacity building programmes, No written capacity building policy and Inadequate support from university management, 203(96\%) indicated no proper needs assessment before organizing capacity building programmes, 194(92\%) indicated inadequate training facilities/ equipment, 182(86\%) indicated no proper evaluation of capacity building programmes for future improvements, $142(67 \%)$ indicated inadequate time to attend capacity building programmes, among others.The barriers to capacity building programmes therefore are Inadequate funds to organize capacity building programmes, Inadequate time to attend capacity building programmes, No proper needs assessment before organizing capacity building programmes, No written capacity building policy, Inadequate support from university management, Inadequate training facilities and equipment, No proper evaluation of capacity building programmes for future improvements and Limited skills of most of the staff being trained has slowed down capacity building programmes

\section{Discussion of Findings}

The findings have revealed facts about the capacity building efforts of library and information professionals in university libraries in in South- South, Nigeria. The study revealed the following:

It was revealed from the study that there were more males than female respondents.

The findings of the study revealed that the capacity building needs of library and information professionals in university libraries were majorly troubleshooting new technologies, academic research, internet search skills, e-library management, and library automation, among others. This findings agrees with the study of Bhatti and Nadeem (2014) which revealed that LIS professionals in university libraries in Pakistan need to develop their capacity in troubleshooting new technologies, endnote, data compression, Internet, social media such as Facebook, Blogger, Flickr, Twitter, and online databases.

Findings show clearly that on the job training, in-house training, participation in professional association, lecture/ discussion and exercises, and job rotation were the major methods of building the capacity of library and information professionals while mentoring, orientation programmes, conferences, workshop, seminars, e-learning, library tours, academic education were used to a low extent. This finding could be as a result of shortage of funds in university libraries to sponsor librarians to conferences, workshop and seminars to build their capacity. This findings agrees with the study of Agadi, Shokeen and Choukimath (2008) that efficient manpower training programmes must be organized from time to time for librarians via Practical hands-on training to library personnel. The 
findings also agrees with the study of Khan and Rafiq (2013) which revealed that practical work is methods of providing in-service training for librarians in Pakistan.

The findings of the study revealed that $59 \%$ of the library and information professionals attend capacity building programmes every two years, $24 \%$ indicated they attend yearly, $11 \%$ indicated twice a year and only $6 \%$ indicated quarterly. It is glaring from these findings that library and information professionals in South- South, Nigeria do not attend capacity building programmes frequently. The study revealed that capacity building programmes has help in the professional development of library and information professionals in the area of upgrading of their professional skills, effective service delivery, increase knowledge of the use of ICT, better communication /interpersonal relationship with users, better e-library management, timely service delivery, and improved understanding about the librarianship profession. The study agrees with the study of Hosein and Bowen-Chang (2011) which clearly demonstrated the effectiveness of cataloguing training in supporting the cataloguers in their thrust to improve and upgrade their professional skills, and thereby facilitate the transfer of knowledge and practices to entry-level cataloguers. The study show clearly that inadequate funds to organize capacity building programmes, no written capacity building policy and Inadequate support from university management, no proper needs assessment before organizing capacity building programmes, inadequate training facilities/ equipment, no proper evaluation of capacity building programmes for future improvements, and inadequate time to attend capacity building programmes are some of the barriers of capacity building programmes in university libraries in South- South, Nigeria. This findings agrees with the study of Owusu-Acheaw (2017); Abba and Dawha (2009) which revealed that insufficient funds is the major barrier affecting capacity building efforts in university libraries.

\section{Conclusion and Recommendations}

The need for building the capacity of library and information professionals in a developing nation like Nigeria cannot be overemphasized especially with the increasing use of information communication technologies in university libraries and other emerging areas in the librarianship profession. Library and information professionals in Nigeria will need to build their capacity in troubleshooting new technologies, academic research, Internet search skills, e-library management, and library automation to be relevant in this 21 century. It is a known fact that Library and information professionals hardly get sponsorship from their university/ library management to attend conferences, workshops and seminars to build their capacity because of shortage of funds. Instead university/ library management leverage on cost effective method of capacity building such as on-the job training, in house training as well as lectures/ discussion and exercises. Capacity building efforts in university libraries has benefited library and information professionals in upgrading of their professional skills, boosted their service delivery and increase knowledge of their use of ICT for enhancement of their services and resources. In-spite of the aforementioned benefits, some factors like inadequate funding, no written capacity building policy, inadequate support from university management, and no proper needs assessment before organizing capacity building programmes are causing barriers to capacity building efforts for library and information professionals in university libraries. In view of the foregoing the following recommendations were made:

1. Capacity building needs should be tailored towards promotion of services and resources and project management skills.

2. Methods of capacity building should include seminar, conferences, workshops, orientation programmes 
3. The frequency of developing capacity should be increased.

4. Regular training should be organise for librarians to boost their competency on cataloguing and classification of library materials

5. Proper needs assessment should be carried out for library and information professionals in order to know areas to channel capacity building efforts in university libraries.

6. Library and information professionals should allocate enough time and be willing to attend capacity building programmes for their self-development.

7. Library and information professionals should attend a minimum of one capacity building programme yearly to equip them with the relevant skills to be relevant in this digital age.

\section{References}

Abba, T., \& Dawha, E.M.K. (2009). Assessment of personnel training needs in the Ibrahim Babangida Library, federal university of technology, Yola, Nigeria. Retrieved from https://www.researchgate.net/publication/28322347_Assessment_of_Personnel_Training_Need s_in_the_Ibrahim_Babangida_Library_Federal_University_of_Technology_Yola_Nigeria

Adekanye, A.E., \&Ogunleye, G. (2016). Training for librarianship development in Nigeria: How do librarians want it? Journal of Library, Educational Media and Information Studies, 8, 82-92.

Agadi, K.B., Shokeen, S., \&Choukimath, P. (2008). Capacity building of library and information professionals in the digital environment. Retrieved from https://www.researchgate.net/publication/267481231_Capacity_Building_of_Library_and_Info rmation_Professionals_in_the_Digital_Environment

Ajeemsha, S., \&Madhusudhan, M. (2012). Continuing professional development for library semiprofessionals in central university libraries of India. International Journal of Library and Information Studies, 4(3), 94-103.

Bamidele, I.A., Omeluzor, S.U., Imam, A., Amadi, H.U. (2013). Training of library assistants in academic library: A study of Babcock University Library, Nigeria. Retrieved from https://journals.sagepub.com/doi/full/10.1177/2158244013503964

Bhattacharjee, S., \& Bhattacharjee, S. (2014). Capacity building through training program in LIS professionals: A survey on various libraries in Barak Valley (Assam). Retrieved from http://ir.inflibnet.ac.in/bitstream/1944/1814/1/2.pdf

Bhatti, R., \& Nadeem, M. (2014). Assessing training needs of LIS professionals: A prerequisite for developing training programs in university libraries of Pakistan. Retrieved from http://www.white-clouds.com/iclc/cliej/cl37BN.pdf

Eke, H. N. (2011). An empirical study of the impact of Nigerian Library Association (NLA) conference attendance on librarians' professional development. In Proceedings of the 49th National Conference and AGM of Nigerian Library Association (pp. 118-139). Akwa, Anambra State, Nigeria.

Hosein, Y., \& Bowen-Chang, P. (2011). Training cataloguing professionals at the University of the West Indies, St Augustine: part 2. Library Review, 60(9), 748-761. doi 10.1108/00242531111176772. 
Idiegbeyan-Ose, J., Ohaegbulam, H., \&Osayande, O. (2015). Conference/Workshop attendance by librarians: Benefits, challenges, and prospects. Chinese Librarianship: An International Electronic Journal, 39, 30-39.

Khan, A., \&Rafiq, M. (2013). Designing effective in-service training for librarians in Pakistan. Library Philosophy and Practice (e-journal). Retrieved from https://digitalcommons.unl.edu/cgi/viewcontent.cgi?article=2576\&context=libphilprac

Malik, M. (2016). Assessment of a professional development program on adult learning theory. Retrieved from https://eric.ed.gov/?id=EJ1091781

Njeze, M.E., \& James, I.J. (2013). Capacity building initiatives in preservation techniques: A case study of Nigerian universities. Brazilian Journal of Information Science, 7(1), 94-108.

Nwabueze, A.U., \&Anike, A.N. (2016). Mentoring strategies in use for professional development of librarians in South-East federal University Libraries. Journal of Applied Information Science and Technology, 9(1), 183-208.

Ogunmodede, T.A., \&Mafelu, M.E. (2012). Capacity Building Programmes for Library Staff in University of Ibadan and University of Lagos Libraries. Samaru Journal of Information Studies, 12(1\&2), 61-67.

Ojowhoh, R. (2016). Staff development and library services in academic libraries in Bayelsa and Delta States. Information Impact: Journal of Information and Knowledge Management, 7(1), $129-137$.

Oke, O. A., \&Oguntuase, F. Z. (2010). Comparative study of training needs of library assistants in two Nigerian Academic Libraries. Owena Journal of Library and Information Science, 3, 1320.

Okiy, R.B. (2004). In-house Staff Training Programme at Delta State University Library, Abraka, Nigeria. Library Hi Tech News, 21(9), 10-12. https://doi.org/10.1108/07419050410572744

Owusu-Acheaw, M. (2017). Professional Development Programmes for Polytechnic Library Staff in Ghana: Challenges and Prospects. Library Philosophy and Practice (e-journal). Retrieved from https://digitalcommons.unl.edu/libphilprac/1581/

United Nations Building Programme. (2009). Capacity development: A UNDP Primer. Retrieved from https://www.undp.org/content/dam/aplaws/publication/en/publications/capacitydevelopment/capacity-development-a-undp-primer/CDG_PrimerReport_final_web.pdf

Word Quotient. (2009). Employee training and development. Retrieved from http://www.wordquotient.com/library/business/employee-training-and-development.html 